P-ISSN: 2615-1723

E-ISSN: 2615-1766

Oktober 2019
Jurnal Riset Pendidikan Dasar

02 (2), (2019) 106-115

Submitted: Juli, Accepted Agustus, Published: Oktober

\title{
PENGEMBANGAN PERANGKAT PEMBELAJARAN INKUIRI TERBIMBING BERBASIS AKTIVITAS HOT PADA TEMA 9 SUBTEMA 1 KELAS IV SD
}

\author{
I Ketut Supadma ${ }^{1}$, Ni Nyoman Kusmariyatni ${ }^{2}$, \& I Gede Margunayasa ${ }^{3}$ \\ Program Studi Pendidikan Guru Sekolah Dasar, Fakultas Ilmu Pendidikan, \\ Universitas Pendidikan Ganesha Singaraja, Indonesia \\ *Korespondensi. E-mail: ketut.supadma22@gmail.com,nym_kusmaryatni@yahoo.co.id, \\ pakgun_pgsd@yahoo.com.
}

\begin{abstract}
Abstrak
Penelitian ini bertujuan untuk menghasilkan produk perangkat pembelajaran inkuiri terbimbing berbasis aktivitas Higher Order Thinking (HOT). Penelitian ini merupakan penelitian pengembangan yang menggunakan model ADDIE, (1) analyze (analisis), (2) design (perancangan), (3) development (pengembangan), (4) implementation (implementasi), (5) evaluation (evaluasi). Subjek penelitian ini adalah 2 orang guru dan 2 orang dosen. Instrumen yang digunakan untuk mengukur kualitas perangkat pembelajaran adalah lembar penelitian menggunakan rating scale berupa lembar penilaian perangkat pembelajaran. Hasil penelitian ini adalah (1) perangkat pembelajaran berupa silabus, Rencana Pelaksanaan Pembelajaran (RPP) dan Lembar Kerja Peserta Didik (LKPD) menggunakan pembelajaran inkuiri terbimbing berbasis aktivitas HOT, (2) produk ini telah divalidasi dengan skor rata-rata silabus sebesar 4,75 dengan kualifikasi sangat baik, skor rata-rata RPP keseluruhan sebesar 4,70 dengan kualifikasi sangat baik, dan skor rata-rata LKPD keseluruhan sebesar 4,70 dengan kualifikasi sangat baik.
\end{abstract}

Kata-kata kunci: Higher Order Thinking; Inkuiri Terbimbing; Perangkat Pembelajaran.

\section{DEVELOPMENT OF LEARNING DEVICES GUIDED INQUIRY BASED ON HOT ACTIVITIES IN THEME 9 SUBTEMA 1 CLASS IV OF ELEMENTARY SCHOOL Abstract}

This study aims to produce guided inquiry learning products based on Higher Order Thinking (HOT) activities. This research is a development research that uses the ADDIE model, (1) analyze (analysis), (2) design (design), (3) development, (4) implementation (implementation), (5) evaluation (evaluation). The subjects of this study were 2 teachers and 2 lecturers. The instrument used to measure the quality of learning devices is the research sheet using the rating scale for the learning device assessment sheet. The results of this study are (1) learning tools in the form of syllabus, Learning Implementation Plans and Student Worksheets using guided activities based HOT learning, (2) these products can be validated with an average syllabus score of 4,75 with very good qualifications, the overall average lesson plan score is 4.70 with excellent qualifications, and the overall average Student Worksheets score is 4.70 with excellent qualifications.

Keywords: High Level Thinking; Guided Inquiry; Learning Devices. 


\section{Jurnal Riset Pendidikan Dasar, 02 (2), Oktober 2019 (106-115)}

I Ketut Supadma, Ni Nyoman Kusmariyatni, \& I Gede Margunayasa

\section{PENDAHULUAN}

Perkembangan ilmu pengetahuan dan teknologi saat ini mengalami peningkatan yang sangat cepat. Untuk bisa mengikuti perkembangan tersebut dibutuhkan sumber daya manusia yang handal dan mampu berkompotensi agar dapat mengikuti perkembangan yang ada. Salah satu kunci untuk mencetak sumber daya manusia yang handal dan memiliki daya saing yang cerdas dapat ditempuh melalui dunia pendidikan. Kemampuan yang dimiliki oleh seseorang tidak bisa berkembang, apabila tidak pernah dilatih dengan cara menempuh dunia pendidikan.

Berpijak pada Abad 21, sudah seharusnya siswa dituntut untuk terus mengembangkan pengetahuan yang dimilikinya dalam proses pembelajaran. Pembelajaran Abad 21 terutama pada Kurikulum 2013 lebih menekankan peserta didik belajar melalui contoh-contoh, penerapan, dan pengalaman dunia nyata (Yusuf, 2015). Pembelajaran Abad 21 lebih menekankan pada pengetahuan peserta didik dengan mengembangkan keterampilan atau potensi yang dimiliki oleh peserta didik (Wijaya, 2016). Empat pilar dalam pembelajaran Abad 21 meliputi: (1) communication (komunikasi), (2) collaboration (kolaborasi), (3) critical thinking (berpikir kritis), dan (4) creativity (kreatif) (Sari, dkk., 2018).

Menurut Permendikbud Nomor 57 Tahun 2014, Kurikulum 2013 bertujuan untuk mempersiapkan manusia agar memiliki kemampuan dan menjadi warga Negara yang beriman, produktif, kreatif, inovatif, dan efektif, serta mampu berkontribusi kepada kehidupan bermasyarakat, berbangsa, bernegara dan peradaban dunia. Proses pembelajaran pada Kurikulum 2013 menekankan pada pendekatan saintifik. Pendekatan saintifik merupakan kegiatan pembelajaran yang dirancang untuk lebih melibatkan siswa secara aktif. Kurikulum 2013 juga dirancang untuk mengembangkan keseimbangan antara pengembangan sikap spiritual dan sosial, rasa ingin tahu, krativitas, kerja sama dengan kemampuan intelektual dan psikomotorik (Anggreani, 2018). Salah satu kemampuan yang ingin dikembangkan dalam kurikulum 2013 yaitu Higher Order Thinking (HOT). HOT merupakan proses berpikir yang menghubungkan, memanipulasi, dan mentranspormasi pengetahuan yang telah mereka miliki untuk berpikir secara kritis dan kreatif dalam mengambil keputusan atau untuk memecahkan masalah yang baru (Rofiah, dkk., 2018).

Hasil observasi yang dilakukan di Gugus XII Kecamatan Buleleng pada 21-23 Januari 2019 saat guru melaksanakan pembelajaran di kelas masih belum mengembangkan kemampuan berpikir siswa secara maksimal. Pembelajaran yang dilakukan masih berpusat pada guru, tanpa memberikan kesempatan pada siswa untuk melatih kemampuan berpikirnya. Dalam proses pembelajaran di kelas, kebanyakan siswa kurang semangat untuk belajar dikarenakan guru masih dominan menggunakan metode ceramah saja. Selain itu, siswa terlihat kurang aktif dalam mengikuti pembelajaran karena kondisi mengajar guru yang demikian.

Hasil wawancara yang dilakukan dengan guru kelas IV di Gugus XII Kecamatan Buleleng, dalam penyusunan perangkat pembelajaran guru hanya mengandalkan perangkat yang disusun oleh kelompok kerja guru (KKG). Menurut guru yang telah diwawancarai, guru mengaku tidak pernah membuat perangkat pembelajaran sendiri, melainkan menunggu perangkat pembelajaran dari KKG di gugus tersebut. Perangkat yang disusun oleh KKG di SDN Gugus XII kecamatan Buleleng sering terlambat dalam penyusunannya, sehingga guru terpaksa download perangkat

Copyright (C2019, JRPD, ISSN 2615 - 1723 (Print), ISSN 2615 - 1766 (Online) 


\section{Jurnal Riset Pendidikan Dasar, 02 (2), Oktober 2019 (106-115)}

I Ketut Supadma, Ni Nyoman Kusmariyatni, \& I Gede Margunayasa

pembelajaran dari internet untuk mengajar. Bahkan guru mengaku jika perangkat dari KKG tersebut terlambat datang, guru tidak menggunakan perangkat dalam mengajar. Padahal kemampuan guru dalam merancang pembelajaran adalah bagian dari kompetensi pedagogik dan kemampuan profesional yang telah dikuasai oleh guru (Khusnah, dkk., 2015).

Berdasarkan analisis dokumen yang telah dilakukan terhadap perangkat pembelajaran yang digunakan guru dalam melaksanakan pembelajaran yaitu silabus sudah sesuai dengan Permendikbud No. 22 Tahun 2016. Akan tetapi, silabus yang disusun belum menunjukkan aktivitas HOT. Rencana Pelaksanaan Pembelajaran (RPP) yang digunakan guru dalam mengajar belum sesuai dengan komponen yang ada pada Permendikbud No. 22 Tahun 2016, materi pembelajaran tidak dicantumkan dalam RPP, indikator masih bersifat umum, dan instrumen penilaiannya belum dicantumkan dengan jelas. Guru mengajar tanpa menggunakan Lembar Kerja Peserta Didik (LKPD).

Berdasarkan karakteristik pembelajaran Abad 21 dan tujuan Kurikulum 2013, perangkat pembelajaran seharusnya dikembangkan untuk mencapai HOT. Perangkat pembelajaran yang digunakan oleh guru harus memadai, terutama dalam penggunaan silabus, RPP dan LKPD. Penggunaan perangkat pembelajaran dalam belajar mengajar harus dilakukan dengan baik dan penggunaan LKPD juga harus memuat petujuk belajar, kompetensi yang ingin dicapai, informasi pendukung pembelajaran, tugas-tugas yang harus diselesaikan oleh siswa, langkah-lagkah kerja, dan penilaian (Depdiknas, 2008).

HOT merupakan kemampuan berpikir yang tidak hanya sekadar menghafal, melainkan dalam pembelajaran di kelas siswa sendiri yang lebih aktif dalam menghubungkan, memanipulasi dan mentranspormasi untuk melatih kemampuan berpikirnya (Rofiah, dkk., 2018). Keterlibatan siswa secara aktif dalam pembelajaran membuat ingatan siswa menjadi kuat, sehingga apa yang telah dipelajari melekat pada diri siswa karena siswa sendiri yang melakukan dan meningkatkan potensi yang dimiliki. Selain itu, tujuan pembelajaran yang diharapkan tercapai dengan baik karena siswa benarbenar memahami apa yang telah dipelajari.

Untuk mengembangkan HOT siswa salah satunya melalui pembelajaran inkuiri terbimbing. Pembelajaran inkuiri merupakan pembelajaran yang menekankan pada kemampuan berpikir kritis dan analitis melalui pemecahan masalah secara ilmiah (Trisnayanti, 2017). Pembelajaran inkuiri merupakan pembelajaran yang mendorong peserta didik untuk mengembangkan pengetahuannya (Wahida, 2016). Tujuan utama dari model pembelajaran inkuiri adalah untuk mengembangkan kemampuan berpikir siswa (Amal \& Basam, 2018).

Implementasi pembelajaran inkuiri terbimbing untuk mencapai kemampuan berpikir tingkat tinggi siswa dalam Kurikulum 2013, dapat dimulai dari penyiapan perangkat pembelajaran. Perangkat pembelajaran Kurikulum 2013 meliputi silabus, RPP, LKPD, buku guru dan buku siswa (Rahayu \& Laksono, 2015). Akan tetapi, berdasarkan hasil analisis dokumen yang dilakukan terhadap silabus, RPP, dan LKPD yang ada perlu disempurnakan. Penyempurnaan perangkat pembelajaran ini, dilakukan melalui penelitian yang berjudul "Pengembangan Perangkat Pembelajaran Inkuiri Terbimbing berbasis Aktivitas Higher Order Thinking (HOT) pada Tema 9 Subtema 1 Kelas IV SD di Gugus XII Kecamatan Buleleng Tahun Pelajaran 2018/2019". Dengan demikian, penelitian ini bertujuan untuk mengembangkan serta mengetahui validitas perangkat pembelajaran Inkuiri Terbimbing berbasis Aktivitas Higher Order Thinking (HOT) pada Tema 9 Subtema 1 Kelas IV SD

Copyright C2019, JRPD, ISSN 2615 - 1723 (Print), ISSN 2615 - 1766 (Online) 


\section{Jurnal Riset Pendidikan Dasar, 02 (2), Oktober 2019 (106-115)}

I Ketut Supadma, Ni Nyoman Kusmariyatni, \& I Gede Margunayasa

di Gugus XII Kecamatan Buleleng Tahun Pelajaran 2018/2019.

\section{METODE}

Penelitian ini merupakan penelitian pengembangan perangkat pembelajaran inkuiri terbimbing berbasis aktivitas HOT yang terdiri dari silabus, Rencana Pelaksanaan Pembelajaran (RPP) dan Lembar Kerja Peserta Didik (LKPD). Penelitian ini menggunakan model pengembangan yaitu model ADDIE (Analyze, Design, Development, Implementation, dan Evaluation) yang merupakan salah satu model desain pembelajaran sistematik. Model ADDIE mudah dipahami, dikembangkan secara sistematik, berpijak pada landasan teoritis desain pembelajaran yang dikembangkan dan memiliki alur proses pengembangan buku ajar yang baik dan benar, sehingga model ini dipilih untuk digunakan dalam penelitian ini (Tegeh dan Jampel, 2017). Model ini terdiri dari 5 langkah yaitu: (1) analisis (Analyze), (2) perancangan (Design), (3) pengembangan (Development), (4) implementasi (Implementation), (5) evaluasi (Evaluation). Akan tetapi, tahap implementasi dan evaluasi tidak dilaksanankan karena keterbatasan waktu.

Prosedur penelitian pengembangan perangkat pembelajaran inkuiri terbimbing berbasis aktivitas HOT berupa silabus, Rencana Pelaksanaan Pembelajaran (RPP), dan Lembar Kerja Peserta Didik (LKPD) yang dilaksanakan dari beberapa tahapan yang dilakukan yaitu: 1) analisis (Analyze), pada tahap ini dilakukan beberapa analisis seperti analisis kebutuhan, analisis karakteristik siswa, dan analisis kurikulum. 2) perancangan (Design), dan 3) pengembangan (Development).

Subjek pada penelitian ini adalah guru dan dosen sebagai ahli pembelajaran. Ahli berperan untuk memperoleh data mengenai validasi isi perangkat pembelajaran yang Copyright (2019, JRPD, ISSN 2615 - 1723 (Print), ISSN 2615 - 1766 (Online) dikembangkan. Sedangkan objek pada penelitian ini adalah kualitas perangkat pembelajaran yang terdiri dari silabus, RPP, dan LKPD Tema 9 Subtema 1 Kelas IV SD.

Data yang dikumpulkan dalam penelitian ini berupa data kualitatif dan data kuantitatif. Data kualitatif didapatkan melalui hasil review dari ahli isi dan ahli pembelajaran berupa tanggapan, masukan, saran dan kritik. Sedangkan data kuantitatif didapat dari instrumen validasi perangkat pembelajaran oleh para ahli.

Metode pengumpulan data penelitian ini adalah metode kuesioner. Metode kuesioner dilakukan mengajukan sejumlah pertanyaan tertulis kepada responden mengenai perangkat pembelajaran yang telah dikembangkan. Metode kuesioner dilakukan untuk mengumpulkan data hasil validasi perangkat pembelajaran oleh ahli pembelajaran. Instrumen yang digunakan untuk mengukur validitas perangkat pembelajaran adalah rating scale berupa lembar penilaian perangkat pembelajaran (silabus, RPP, LKPD).

Analisis yang digunakan dalam penelitian ini yaitu, melalui skor rata-rata (mean). Rumus ini digunakan untuk mendeskripsikan tinggi rendahnya skor yang didapatkan dari perangkat pembelajaran yang dikembangkan.

\section{HASIL DAN PEMBAHASAN Hasil Penelitian}

Hasil dari penelitian ini berupa produk silabus, 6 RPP, dan 6 LKPD Tema 9 Subtema 1 Kelas IV SD. Hasil validitas perangkat pembelajaran menunjukkan bahwa perangkat pembelajaran yang dikembangkan tergolong sangat baik dengan nilai rata-rata silabus sebesar 4,75, nilai rata-rata keseluruhan RPP sebesar 4,70, dan nilai ratarata keseluruhan LKPD sebesar 4,70. Hasil validasi kualifikasi perangkat pembelajaran dapat dilihat pada gambar 1, gambar 2, dan gambar 3. 
Jurnal Riset Pendidikan Dasar, 02 (2), Oktober 2019 (106-115)

I Ketut Supadma, Ni Nyoman Kusmariyatni, \& I Gede Margunayasa

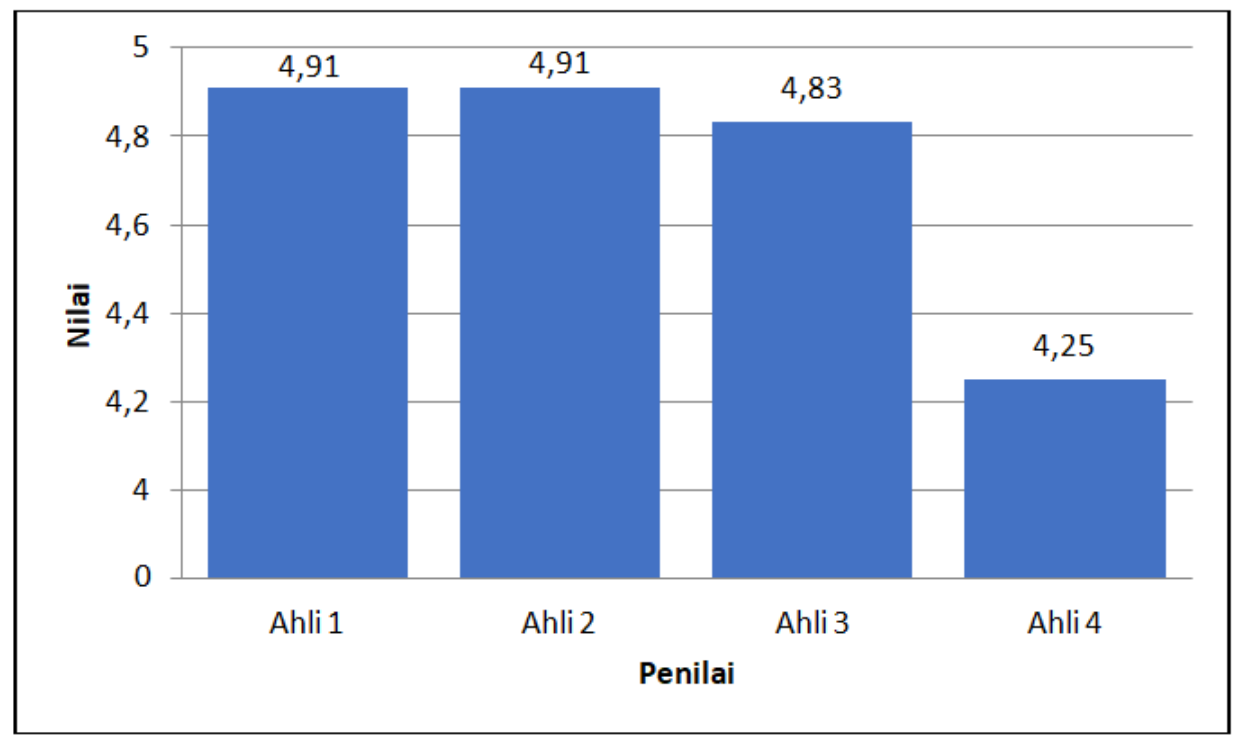

Gambar 1. Grafik Penilaian Silabus

Berdasarkan hasil analisis data yang telah dilakukan pada perangkat pembelajaran silabus, maka didapatkan nilai rata-rata sebesar 4,75 dengan kualifikasi sangat baik.

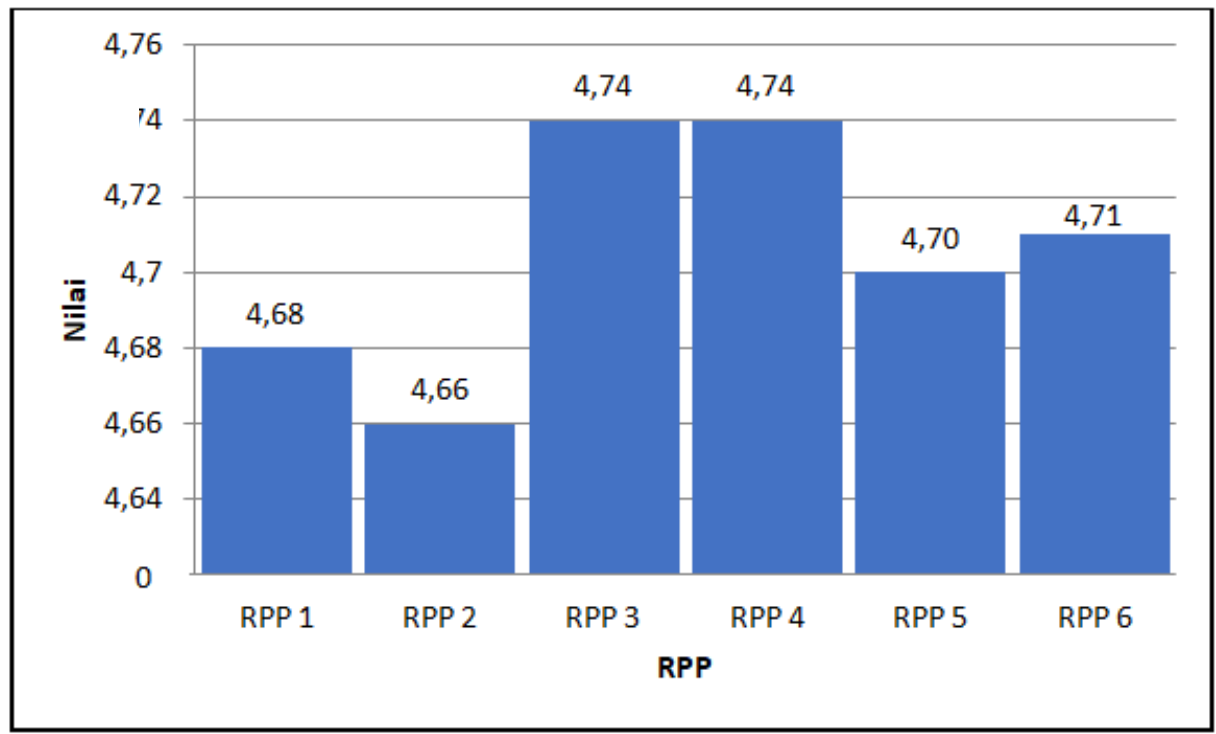

Gambar 2. Grafik penilaian RPP

Berdasarkan hasil analisis data yang telah dilakukan pada perangkat Rencana Pelaksanaan Pembelajaran
(RPP), maka didapatkan skor rata-rata sebesar 4,68 untuk pembelajaran 1, ratarata 4,66 untuk pembelajaran 2, rata-rata

Copyright (C2019, JRPD, ISSN 2615 - 1723 (Print), ISSN 2615 - 1766 (Online) 
Jurnal Riset Pendidikan Dasar, 02 (2), Oktober 2019 (106-115)

I Ketut Supadma, Ni Nyoman Kusmariyatni, \& I Gede Margunayasa

4,74 untuk pembelajaran 3 , rata-rata 4,74 untuk pembelajaran 4 , rata-rata 4,7 untuk pembelajaran 5 , dan rata-rata 4,71 untuk pembelajaran 6. Sedangkan untuk skor rata-rata keseluruhan perangkat RPP yaitu mendapat skor 4,70 . Rata-rata tiap RPP maupun rata-rata keseluruhan RPP jika dikonversikan dengan Penilaian Acuan Patokan (PAP) skala lima, semuanya berada pada kualifikasi sangat baik.

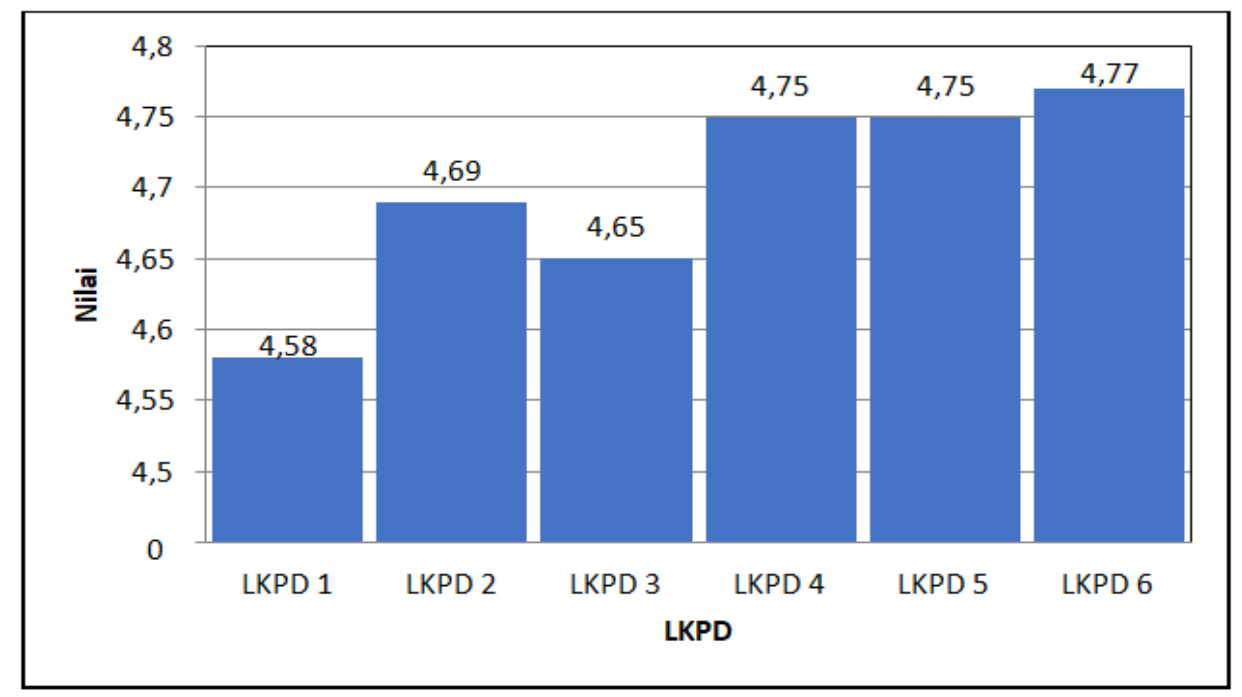

Gambar 3. Grafik penilaian LKPD

Berdasarkan hasil analisis data yang telah dilakukan pada perangkat Lembar Kerja Peserta Didik (LKPD), maka didapatkan skor rata-rata sebesar 4,58 untuk LKPD pembelajaran 1, ratarata 4,69 untuk LKPD pembelajaran 2, rata-rata 4,65 untuk LKPD pembelajaran 3, rata-rata 4,75 untuk LKPD pembelajaran 4 , rata-rata 4,75 untuk LKPD pembelajaran 5, dan rata-rata 4,77 untuk LKPD pembelajaran 6. Sedangkan untuk nilai rata-rata keseluruhan perangkat LKPD yaitu mendapat skor 4,70. Rata-rata tiap RPP maupun ratarata keseluruhan RPP jika dikonversikan dengan Penilaian Acuan Patokan (PAP) skala lima, semuanya berada pada kualifikasi sangat baik.

\section{PEMBAHASAN}

Berdasarkan deskripsi dari hasil penelitian yang telah dipaparkan sebelumnya, pengembangan perangkat pembelajaran inkuiri terbimbig berbasis aktivitas Higher Order Thinking (HOT) dengan model ADDIE melalui tahap analyze, design, development, implementation, dan evaluation. Pemilihan model ini didasari karena model ini mudah dipahami dan dikembangkan secara sistematis. ADDIE merupakan sebuah rangkaian proses desain instruksional yang terdiri dari lima tahapan, seperti analyze, design, development, implementation dan evaluation (Isya, 2017). Kelima tahapan tersebut dikembangkan secara 


\section{Jurnal Riset Pendidikan Dasar, 02 (2), Oktober 2019 (106-115)}

I Ketut Supadma, Ni Nyoman Kusmariyatni, \& I Gede Margunayasa

sistematis dengan tahapan-tahapan yang dirancang berdasarkan landasan teoretis desain pembelajaran. Model ADDIE mudah untuk dipahami dan dikembangkan melalui langkah-langkah yang sistematik. Namun, diperjelas kembali bahwa penelitian ini berfokus pada pengembangan perangkat pembelajaran saja, sehingga tahap implementation dan evaluation tidak dilaksanakan pada penelitian ini.

Tahap analyze dilakukan tiga analisis seperti, analisis kebutuhan, analisis karakteristik siswa, dan analisis kurikulum. Dari hasil analisis kebutuhan yang telah dilakukan dapat diketahui bahwa masih terbatasnya perangkat pembelajaran yang memanfaatkan kemampuan siswa secara maksimal dan melibatkan siswa secara aktif dalam pembelajaran. Perangkat pembelajaran yang dikembangkan harus disesuaikan dengan analisis kebutuhan (Pariatna, dkk., 2015). Oleh karena itu, disusun perangkat pembelajaran yang lebih memanfaatkan kemampuan siswa secara maksimal dan aktif dalam proses pembelajaran.

Tahap design merupakan tahap dilakukannya perencanaan perangkat pembelajaran inkuiri terbimbing berbasis aktivitas HOT yang berupa silabus, Rencana Pelaksanaan Pembelajaraan (RPP) dan Lembar Kerja Peserta Didik (LKPD). Penyusunan perangkat silabus dilakukan dengan unsur-unsur, yaitu 1) sampul, 2) identitas sekolah, 3) kompetensi inti, 4) kompetensi dasar, 5) tema, 6) materi pokok, 7) pembelajaran, 8) penilaian, 9) alokasi waktu, 10) sumber belajar. Penyusunan Rencana Pelaksanaan Pembelajaran (RPP) dilakukan dengan unsur-unsur, yaitu 1) identitas sekolah, 2) identitas mata pelajaran, 3) kelas/semester, 4) materi pokok, 5) alokasi waktu, 6) tujuan pembelajaran, 7) kompetensi dasar dan indikator, 8) materi pembelajaran, 9) metode pembelajaran, 10) media pembelajaran, 11) sumber belajar, 12) langkah-langkah pembelajaran, 13) penilaian). Selanjutnya penyususnan Lembar Kerja Peserta Didik (LKPD) dilakukan dengan unsur-unsur, yaitu 1) judul/sampul, 2) kompetensi dasar, 3) indikator, 4) tujuan, 5) petujuk kerja, dan 6) soal-soal yang harus dikerjakan.

Tahap development merupakan tahap dilakukannya pengembangan perangkat pembelajaran inkuiri terbimbing berbasis aktivitas HOT berupa silabus, Rencana Pelaksanaan Pembelajaran (RPP) dan Lembar Kerja Peserta Didik (LKPD). Setelah dikembangkan, kemudian dilakukan pengujian perangkat yang telah dikembangkan dengan pemberian koesioner validitas kepada guru dan dosen sebagai ahli pembelajaran. setelah dilakukan penilaian, maka diperoleh saran atau komentar dari ahli. Kemudian dilakukan revisi untuk penyempurnaan perangkat yang telah dibuat.

Berdasarkan uji perangkat yang telah dilakukan, adapun temuan dari penelitian ini adalah rata-rata keseluruhan dari perangkat yang telah dikembangkan, yaitu perangkat silabus mendapat rata-rata dengan nilai 4,75, perangkat Rencana Pelaksanaan Pembelajaran (RPP) mendapat rata-rata dengan nilai 4,71, dan Lembar Kerja Peserta Didik (LKPD) mendapat ratarata dengan nilai 4,70. Jika dikonversikan ke dalam Penilaian Acuan Patokan (PAP) skala lima berada pada kategori 


\section{Jurnal Riset Pendidikan Dasar, 02 (2), Oktober 2019 (106-115)}

I Ketut Supadma, Ni Nyoman Kusmariyatni, \& I Gede Margunayasa

sangat baik. Sehingga dapat dikatakan bahwa pengembangan perangkat pembelajaran inkuiri terbimbing berbasis aktivitas HOT tergolong sangat baik. Dari pemaparan di atas, dapat diketahui bahwa pengembangan perangkat pembelajaran inkuiri terbimbing berbasis aktivitas HOT tergolong sangat baik.

Berdasarkan pembahasan penelitian tersebut, diketahui bahwa perangkat pembelajaran inkuiri terbimbing berbasis aktivitas HOT yang dikembangkan sudah memenuhi validasi dan berada pada kualifikasi sangat baik, sehingga perangkat tersebut layak untuk diimplementasiikan. Hasil penelitian ini sejalan dengan hasil penelitian Yunita yang memperoleh bahwa perangkat pembelajaran model inkuiri terbimbing topik klasifikasi makhluk hidup di SMP hasilnya cukup valid, praktis, dan efektif. Rata-rata penilaian pakar terhadap perangkat pembelajaran yang dibuat sebesar 79,11\% dengan kategori cukup valid. Keterlaksanaan RPP mencapai 3,72 tergolong kategori sangat baik. Respon positif siswa terhadap proses pembelajaran mencapai $93 \%$. Perangkat pembelajaran yang dirancang juga tergolong efektif berdasarkan hasil belajar kognitif produk dan kognitif prosestuntas melebihi batas ketuntasan $75 \%$ yaitu 78,26\% (Yunita, 2016).

Selain itu, hasil penelitian ini juga sejalan dengan hasil penelitian Baharuddin dkk yang menunjukkan bahwa: 1) validitas perangkat pembelajaran IPA berbasis inkuiri terbimbing dengan tugas proyek yang dikembangkan berkategori valid; 2) keterlaksanaan RPP berkategori baik; 3) aktivitas siswa menunjukkan ke arah pembelajaran siswa aktif membangun pengetahuannya sendiri melalui proses inkuiri; 4) siswa memberikan respon positif terhadap proses pembelajaran; 5) hasil belajar siswa baik dari aspek sikap, pengetahuan, dan keterampilan mencapai ketuntasan. Berdasarkan hasil penelitian di atas dapat disimpulkan bahwa perangkat pembelajaran IPA berbasis pembelajaran inkuiri terbimbing dengan tugas proyek pada materi sistem ekskresi sudah valid, praktis dan efektif sehingga layak digunakan dalam pembelajaran dan terbukti efektif untuk menuntaskan hasil belajar siswa (Baharuddin, Sifak, \& Toeti, 2017).

Hasil penelian yang mendukung penelitian ini juga adalah hasil penelitian Nafrianti dkk yang menunjukkan bahwa perangkat pembelajaran inkuiri terbimbing berbantuan PhET pada materi Listrik Dinamis layak digunakan untuk meningkatkan keterampilan berpikir kritis siswa (Nafrianti, Imam, \& Erman, 2016). Begitu juga didukung oleh hasil penelitian Rizaldi yang menunjukkan bahwa hasil analisis validasi perangkat pembelajaran Fisika berbasis inkuiri terbimbing pada materi listrik dinamis yang telah dikembangkan berada pada kategori sangat valid dengan nilai $86,3 \%$. Analisis praktikalitas berdasarkan angket keterlaksanaan RPP dengan nilai $85,6 \%$, angket respon guru dengan nilai $84,08 \%$ dan angket respon siswa dengan nilai $75,6 \%$ diperoleh bahwa perangkat sangat praktis. Hasil uji efektivitas dinyatakan bahwa perangkat pembelajaran yang dikembangkan efektif karena perangkat dapat meningkatkan kompetensi siswa pada kompetensi pengetahuan dengan nilai 78,7 , sikap dengan nilai 75,4 dan keterampilan proses sainsnya dengan nilai 75,3. Dengan demikian, perangkat

Copyright (C2019, JRPD, ISSN 2615 - 1723 (Print), ISSN 2615 - 1766 (Online) 


\section{Jurnal Riset Pendidikan Dasar, 02 (2), Oktober 2019 (106-115)}

I Ketut Supadma, Ni Nyoman Kusmariyatni, \& I Gede Margunayasa

pembelajaran fisika berbasis model inkuiri terbimbing untuk menstimulus keterampilan proses sains siswa pada materi listrik dinamis sangat valid, sangat praktis dan efektif untuk diterapkan pada proses pembelajaran (Rizaldi, 2017).

\section{SIMPULAN}

Berdasarkan hasil penelitian dan pembahasan, maka dapat diambil simpulan bahwa perangkat pembelajaran inkuiri terbimbing berbasis aktivitas Higher Order Thinking (HOT) pada Tema 9 Subtema 1 Kelas IV SD berupa silabus, RPP, dan LKPD memperoleh skor dengan nilai rata-rata skor penilaian silabus adalah 4,75 , rata-rata skor penilaian keseluruhan RPP adalah 4,70, dan rata-rata skor penilaian keseluruhan LKPD adalah 4,70. Perangkat pembelajaran inkuiri terbimbing berbasis aktivitas Higher Order Thinking (HOT) pada Tema 9 Subtema 1 Kelas IV SD berada pada kualifikasi sangat baik.

Beberapa saran yang dapat disampaikan pada penelitian ini dalam rangka pengembangan perangkat pembelajaran adalah (1) kepada guru, agar dapat menggunakan perangkat pembelajaran inkuiri terbimbing berbasis aktivitas HOT dalam mengajar dan dapat dijadikan contoh untuk merancang perangkat pembelajaran pada subtema lainnya. Selanjutnya, kepada kepala sekolah, bisa mengarsip dan dapat mefasilitasi guru untuk mengembangkan perangkat pembelajaran untuk peningkatan mutu pendidikan. Kepada peneliti lain, hasil penelitian ini dapat dijadikan referensi atau pedoman dalam hal pengembangan perangkat pembelajaran yang sejenis dan dapat dilanjutkan pada tahap implementasi menggunakan penelitian eksperimen atau penelitian tindakan.

\section{DAFTAR PUSTAKA}

Amal, A., \& Basam, F. (2018). Pengembangan perangkat pembelajaran IPA berbasis inkuiri terbimbing terhadap pencapaian hasil belajar siswa sekolah dasar. Jurnal Riset Pendidikan Dasar, 1(2), 116-123.

Anggreani, Erni Luviana, Ika Priantari, \& H. Helfien Harianto. (2018). Pengembangan perangkat pembelajaran berbasis inkuiri pada materi jamur. Jurnal Biologi dan Pembelajaran Biologi, 3(1), 2528-1615.

Baharuddin, Sifak Indana, \& Toeti Koestiari. (2017). Perangkat pembelajaran IPA berbasis inkuiri terbimbing dengan tugas proyek materi sistem ekskresi untuk menuntaskan hasil belajar siswa SMP. Jurnal IPA dan Pembelajaran IPA (JIPI), 1(1): 81-97.

Depdiknas. (2008). Panduan Pengembangan Bahan Ajar. Jakarta: Depdiknas.

Isya, Muhammad Andi. (2017). Pengembangan model pembelajaran instruksional design dengan model ADDIE mata pelajaran PAI pada materi mengulang-ulang hafalan Surah Al Ma'un dan al Fil secara klasikal, kelompok dan individu kelas V SDN Gedongan 2 Kota Mojokerto. Jurnal Ilmiah Pendidikan Agama Islam, 7(1), 71-80.

Khusnah, Laila, Ibrohim, \& Abdul Ghofur. (2015). Pengembangan perangkat pembelajaran IPA terpadu berbasis salingtemas dan inkuiri terbimbing untuk membentuk pemahaman terintegrasi peserta didik SMP. Jurnal Pendidikan Sains, 3(4), 149-157.

Nafrianti, Neti, Z.A. Imam Supardi, \& Erman. (2016). Pengembangan perangkat pembelajaran inkuiri terbimbing berbantuan Phet pada materi listrik dinamis untuk meningkatkan keterampilan berpikir kritis siswa. Pendidikan Sains Pascasarjana Universitas Negeri Surabaya, 6(1), 1100-1106.

Pariatna, I Wayan Jus, Ida Bagus Nyoman Sudria, \& Ngadiran Karto Wasono. (2015). Pengembangan perangkat pembelajaran inkuiri terbimbing pada 
Jurnal Riset Pendidikan Dasar, 02 (2), Oktober 2019 (106-115)

I Ketut Supadma, Ni Nyoman Kusmariyatni, \& I Gede Margunayasa

topik laju reaksi. Jurnal Wahana

Matematika dan Sains, 9(1), 38-50.

Rahayu, Rina \& Endang, W. Laksono.

(2015). Pengembangan perangkat pembelajaran IPA berbasis problembased learning di SMP. Jurnal Kependidikan, 45(1), 29-43.

Rizaldi, Rachmat. (2017). Pengembangan perangkat pembelajaran Fisika SMA berbasis model inkuiri terbimbing untuk menstimulus keterampilan Proses sains siswa pada materi listrik dinamis. Journal of Physics and Science Learning (PASCAL), 1(2), 25-34.

Rofiah, Emi, Nonoh Siti Aminah, \& Widha Sunarno. (2018). Pengembangan modul pembelajaran IPA berbasis High Order Thinking Skill (HOTS) untuk meningkatkan kemampuan berpikir kritis siswa kelas VIII SMP/MTs. Jurnal Pendidikan IPA, 7(2), 285-296.

Trisnayanti, Kadek Dewi. (2017). Pengaruh model pembelajaran inkuiri bernuansa outdoor study terhadap penguasaan kompetensi pengetahuan IPA siswa kelas V. e-journal PGSD Universitas Pendidikan Ganesha Mimbar PGSD, 5 (2), 1-10.

Wijaya, Etistika Yuni, Dwi Agus Sudjimat, \& Amat Nyoto. (2016). Transformasi pendidikan abad 21 sebagai tuntutan pengembangan sumber daya manusia di era global. Prosiding Seminar Nasional Pendidikan Matematika 2016 Universitas Kanjuruhan Malang, 1(26), 263-278.

Yunita, Erma. (2016). Pengembangan perangkat pembelajaran menggunakan model inkuiri terbimbing topic klasifikasi makhluk hidup di SMP. JINoP (Jurnal Inovasi Pembelajaran), 2(1), 282-292.

Yusuf, Irfan, Sri Wahyu Widyaningsih, \& Dewi Purwati. (2015). Pengembangan perangkat pembelajaran fisika modern berbasis media laboratorium virtual berdasarkan paradigma pembelajaran abad 21 dan kurikulum 2013. Jurnal Pendidikan Fisika, 4(2), 189-200. 